\title{
Implementation Of Marketing Strategies In Increasing Sales Volume
}

\author{
Andi Haslindah ${ }^{1}$, Aminuddin Hamdat ${ }^{2}$, Mora $^{3}$, Hafidz Hanafiah ${ }^{4 *}$ \\ 1 Islam Makassar University, Indonesia \\ ${ }^{2}$ Nitro, Institute of Business and Finance, Indonesia \\ ${ }^{3}$ Indonesian Muslim University, Indonesia \\ ${ }^{4}$ Bina Bangsa University, Indonesia \\ ${ }^{*}$ Corresponding author: \\ Email: hafidzhanafiah31237@gmail.com
}

\begin{abstract}
.
Marketing strategy is the means to communicate company goals with the direction to be taken to achieve goals to stakeholders or parties who have decisions in the company. So as the marketing strategy is a very important value to be applied by service and non-service companies to remain competitive.The purpose of this study was to identify and understand the implementation of marketing strategies in manufacturing companies. The method used in this research is descriptive qualitative with the type of case study research on the object of research using the methods of observation, interviews, and documentation. While the data analysis technique using the SWOT analysis technique (Strength, Weakness, Opportunity, Threat).The results showed that through the EFAS (External Strategic Factor Analysis Summary) analysis, a total score of 2.95 was obtained and the IFAS (Internal Strategic Factor Analysis Summary) analysis obtained a total score of 2.25. This strategy focuses on efforts to maintain the capabilities of the company and use them to seize the opportunities that exist. Market penetration and product development are strategies that are usually applied by companies in this position.
\end{abstract}

Keywords: Marketing Strategy, Sales Volume

\section{INTRODUCTION}

Economic development in Indonesia is an important part of national development with the ultimate goal of improving people's prosperity. The development of the times and technology requires the company's life to adapt to existing situations and conditions. A company that is not able to adapt to its environment sooner or later will be eliminated from the business environment, so it is necessary to think of a good strategy so that company continuity occurs and helps in achieving the goals that have been set appropriately. Thus, more and more companies are growing in Indonesia, causing the competition that has existed to become more intense increasingly. To be able to survive and develop in such conditions requires careful planning and not only long-term plans that are focused on the survival of the company itself.Refers to the problem of globalization in all life, in which economic activities are currently faced with free trade or global trade. According to Kotler and Armstrong (2001:7), marketing is a social and managerial process that makes individuals and groups obtain what they need and want, through creation and exchange.

Reciprocate products and value with others. Boyd, Walker, and Larreche (2004:4) define that marketing as a social process that involves important activities that enable individuals and companies to get what they need and want through exchanges with other parties and to develop exchange relationships.Marketing is one of the functions within the company which is often referred to as the spearhead of the success of a company because all functions within the company are interconnected systems, influence each other, and cannot be separated. Called the spearhead because this function is a function that is directly in contact with the company's external environment, namely with customers as targets for the products or services produced by the company.However, the marketing strategy implemented by a company in addition to considering market conditions that are always changing dynamically must also consider the type of product produced by the company. Whether a company produces physical products (manufacturing) or a services industry. 
This research was conducted in one of the companies engaged in manufacturing, namely a manufacturing company engaged in the garment business. In the implementation or implementation of all company programs, it requires an appropriate and effective marketing plan, because in the business world there is a possibility of competition, so the company can analyze the strengths, weaknesses, opportunities, and threats that hinder the growth and development of the company's market as well as its objectives. company to be able to continue to increase sales volume so that the target is achieved as much as possible.

Based on these problems, the researchers are interested in researching with the title "Implementation Of Marketing Strategies In Increasing Sales Volume". The main problems in this research are 1) What is the marketing strategy in increasing sales volume?, 2) What are the internal factors (IFAS) and external factors (EFAS) concerning the level of sales volume?.

\section{Marketing}

Entrepreneurs have started to recognize that marketing is an important factor to achieve the success of the company, especially in terms of marketing their products to achieve the ultimate goal of profit for the company. Every company will try hard to know there are new ways and philosophies involved in marketing activities called the marketing concept. The definition of marketing according to Jerome McCarthy and William D. Perreault (1996:9) says that marketing is a social process that directs the economic flow of goods and services from producers to consumers, which effectively adjusts supply and demand and achieves societal goals.According to Kotler and Armstrong (2001:7) marketing is a social and managerial process that makes individuals and groups obtain what they need and want, through creating and exchanging products and values with others. Boyd, Walker, and Larreche (2004:4) define that marketing as a social process involving important activities that enable individuals and companies to get what they need and want through exchanges with other parties and to develop exchange relationships.

While Gregory Chandra (2005:1) suggests that marketing includes social and managerial processes by which individuals and groups obtain what they need and want through the creation, supply, and exchange of goods and services of value to one another. In addition, marketing can also be defined as the process of planning and implementing the conception, pricing, promotion, and distribution of ideas, goods, and services to satisfy individual and organizational goals.From all the definitions above, we can see that marketing as a system and related activities, aimed at planning, pricing, promoting, and distributing goods and services to a group of buyers that is universally applicable and also marketing is an important factor for achieving company success, especially in terms of marketing their products.

\section{Marketing strategy}

To survive and win the competition in business, companies need to establish a strategy that is used as a basis in the management decision-making process based on a review of many factors, both internal and external. Strategy is a way to overcome and anticipate any problems that arise and take advantage of opportunities for the future.According to Kotler, (2003: 191) suggests that strategy is the glue that aims to build and provide a consistent value proposition and build a different image to the target market. Meanwhile, Basu Swasta and Irawan (2003:67) stated that strategy is a plan that is prioritized to achieve that goal (company). Boyd, Walker, and Larreche (2000:29) define that strategy as a fundamental pattern of current and planned goals, resource direction, and interaction of the organization with markets, competitors, and other environmental factors.

The meaning of this strategy is that managers play an active, conscious, and rational role in formulating organizational strategy.From these various definitions, it is clear that strategy is an action that must be carried out in every company to achieve the company's expected goals. Because if a company does not have a strategy, it will result in each organizational unit not having the same direction or estuary in achieving goals and not having integrated activities between one unit and another.Thus the marketing strategy according to Kotler (1997:75) says that is a marketing logic and based on that the business unit is expected to achieve its marketing goals. A marketing strategy is a statement (either implicitly or explicitly) about how a brand or product line achieves its goals. 


\section{Benefits of marketing strategy}

The benefit of a marketing strategy for the company is that it is the basis and direction for the company to achieve company goals. This is following what Purnomo and Zulkieflimansyah said that marketing strategies can be used as a means to communicate company goals with the direction to be taken to achieve these goals to parties who have an interest in the company.So it is clear that the marketing strategy is one of the most important points and must be applied by all service and non-service companies. Any careful planning and little risk will help the company to stay competitive.

\section{Market segmentation}

Market segmentation is dividing the market into certain segments that are targeted for sales to be achieved with a certain marketing mix (Swasta, 2003:122). This activity requires the ability to effectively measure sales opportunities in various market segments and the ability to choose the right marketing mix for the selected market segment.Market segmentation can be formulated as a process where marketers place different market groups (heterogeneous) into one group that has similarities (homogeneous), (Amirullah, 2002:10). The purpose of market segmentation is to develop a unique marketing program that is tailored to market characteristics. This action is taken to meet the expectations of consumers who want something unique compared to the existing ones. Market segmentation is very helpful for producers to create a product that can meet the needs of the target market.

\section{METHOD}

\section{Types of research}

Before conducting research, it is necessary to know in advance about the approach and type of research used. It aims to simplify the solution. Judging from the type of problem being investigated, the technique used, as well as the place and time of the research, this research uses a case study approach. According to Mulyana (2003:201), a case study is a comprehensive description and explanation of various aspects of an individual, a group, an organization (community), a program, or a social situation. The type of research that the author conducts is descriptive qualitative research, the data collected is in the form of words, pictures, and not numbers, or in the form of data quotes. (Moleong, 2000:6)

\section{Data Sources and Data Collection Methods}

According to Arikunto (2002:107), the source of the data in the study is the subject from which the data can be obtained.Primary data, data obtained through direct observation of the source (people or informants) which was deliberately chosen by the researcher to obtain data that has relevance to this problem. While secondary data, data obtained other than primary data. The data are in the form of documents, notes, books related to the smooth running of the research.Data collection methods in this study used the following methods: 1) Interview, 2) Observation, 3) Documentation data.

\section{Data Analysis Method}

1. Internal-External Analysis (IE-Matrix) $\rightarrow$ This matrix was developed from the General Electric model (GE-Model). The parameters used include the parameters of the company's internal strength and external influences faced. The purpose of using this model is to obtain a more detailed corporate-level business strategy (Rangkuti, 2005:42).

2. SWOT (Strength-Weakness-Opportunity-threat) Matrix Analysis $\rightarrow$ analysis of opportunities and threats, strengths and weaknesses of the company.

3. SWOT Diagram Analysis $\rightarrow$ The SWOT diagram analysis conducted by Pearce and Robinson (1997:232) is divided into several strategies in four different cells, namely cell one aggressive strategy, cell two diversification strategy, cell three self-improvement strategy, and cell four defensive strategies, namely: a. Cell 1: Aggressive strategy, b. Cell 2: Diversification strategy, c. Cell 3: Self-improvement strategy, and d. Cell 4: Defensive strategy. 


\section{RESULTS AND DISCUSSION \\ Environmental Analysis}

The environment is a dynamic and ever-changing factor. Changes occurring in the external environment can be an opportunity or even a threat, and changes in the internal environment can be a strength or weakness for the company. Environmental analysis is one of the important elements in the implementation of marketing strategy. Through environmental analysis, companies can produce some information needed to assess the current and future conditions of the company and become a reference for companies in implementing marketing strategies.

\section{External Environment Analysis}

The company's external environment is the company's interaction with the environment outside the company's scope, which tends to be difficult to control. Changes in the external environment will encourage companies to make adjustments so that companies can maximize opportunities and minimize existing threats. In carrying out its activities, the company faces an external environment in the form of a remote environment, an industrial environment, and an operational environment, each of which is analyzed to obtain information for strategy formulation.

a) Distant Environment

Several factors in the remote environment that affect the company's business activities include:

- Economic Factor

Economic factors relate to the nature and direction of the economic system in which a company operates. This factor is very vulnerable and is often taken into consideration in decisionmaking efforts by management within the company.

The positive trend of economic growth is a favorable condition for the development of the business world in general. In reverse, a negative trend will hinder or be detrimental to the development of the business world in general. The national economy grew sluggishly and fluctuated, but showed a positive trend, which was in the range of $5.9 \%$ in the following year, increasing to $6.4 \%$, even the President said that Indonesia's economic growth rate was close to $7 \%$ although it was sluggish. Economic growth affects the company's activities although it is not too significant.

While the level of income per capita is one of the indicators used to measure the population welfare level. With the increase in the level of per capita income, the purchasing power of the people also increases. This can be an opportunity for the company because it indicates an increasing purchasing power of potential consumers.

- Political Factor

The business activities of a company are strongly influenced by the direction, policies, and political stability of the country in which the company operates. Political factors can be an obstacle if the conditions are not stable, and otherwise, if it's stable it will be smooth. Indonesia's current political condition can be said to be stable and conducive, although sometimes it is colored by demonstrations related to government policies.

Empowerment of Micro, Small and Medium Enterprises (MSMEs) launched by the government is related to increasing economic growth, through several programs regarding guarantee funds, licensing regulations, development of consulting services, as well as strengthening large business partnerships and MSMEs. However, what is still a threat to companies from government policies is the low import duty $(\mathrm{BM})$ tariff for garment products, which is $0 \%-15 \%$. This low tariff allows imported goods to freely enter and displace domestic products, through prices that are still cheap.

- Socio-Cultural Factors

The company's external environment always faces different social conditions, which are influenced by culture, demography, ecology, religion, education, and ethnicity. This socio-cultural factor affects the opportunities and challenges in achieving the goals of an organization, the company tries to seize the opportunities that exist and develop its business through products made 
of cloth. Where the product is a product that is always in demand wherever and whenever it is timeless.

- Technological Factor

Technology changes rapidly and drastically, providing convenience, reducing production costs, and improving the quality of a product. Technology not only offers good opportunities in achieving goals but also challenges and threats in their implementation. It takes a large investment by the company in choosing the right technology and following the activities and capabilities of the company. The machines and equipment that the company uses today are practically obsolete and need to be replaced with new machines and new technology, to increase the quantity and quality of their products.

b) Industrial Environment

The industrial environment has a fairly large competitive effect on company performance. The analysis of the industrial environment includes six things, namely the threat of new entrants, the threat of substitute products, the power of buyers, the strength of suppliers, and competition among companies in the industry.

- Newcomer Threat

Companies need to be aware of the entry of new companies into existing industries. The garment industry is an industry that has big barriers to entry for companies that want to enter it. New companies that want to enter this industry require large capital to invest in the machines and tools used, besides that the company must also be able to increase effectiveness and efficiency in reducing prices to compete. The company considers new entrants not to be a too significant threat in the struggle for existing market share.

- The Threat of Substitute Products

As a basic human product in the form of clothing, garments have many kinds of substitute products when viewed from the type of material used. The company considers products made from fabrics as a threat, but not too big because this involves considering the tastes of the people who use them.

- Buyer Power

Buyers can influence the company in terms of price, quality, and service, lower prices and improve quality and service. With so many choices of types and brands, it is easy for consumers to switch to choosing goods with better quality and prices. The company has been trying to establish quality and competitive prices, especially for similar products.

- Competition Among Members in the Industry

Competition affects the company's policies and performance to be able to win it. Competition in the garment industry is very tight with competitive quality and prices. This competition is not only enlivened by local companies but also products from abroad. This has become a major threat to the Company in its sales activities.

2. Internal Environmental Analysis

Internal environmental analysis shows the strengths and weaknesses of the company that affects the effectiveness of achieving company goals, by optimizing and utilizing the strengths and minimizing existing weaknesses. Analysis of the company's internal environment can be carried out based on a functional approach, carried out by analyzing marketing, production, human resources, and financial factors.

a. Marketing

The influencing factors in the Company's marketing function consist of the 4Ps, namely product, place, price, and promotion. In terms of products produced by the Company is still limited. The products produced vary according to the model. The models of the products produced by the Company are considered by the company as models that are generally widely circulated and in demand by consumers. 


\section{b. Production}

The production activities carried out by the Company are considered to have been effective and efficient. So far, the company runs a semi-automatic production process, where some use machines and some use human power. The current condition of the machines that are owned can be said to be obsolete and require replacement to more modern machines to improve quality, as well as effectiveness and efficiency.

c. Finance

The company's financial condition will determine business activities in the future. So far, the Company has not experienced any problems in fulfilling its financial obligations or obligations with third parties, or in other words, the finances in the company have been managed as well as possible.

\section{Opportunities and Threats}

Based on an analysis of the external environment faced by the Company, opportunities and threats can be identified that can affect the company's position. Broadly speaking, the opportunities and threats from the analysis of the external environment can be stated as follows:

1. Opportunity

Opportunity is an opportunity that tends to provide benefits for the company. The following are several factors regarding the opportunities the Company has:

a) The improving economic conditions, marked by a positive and increasing trend of economic growth, benefited the business world, especially the Company, to be able to further increase and expand its potential market.

b) The increasing population provides a great opportunity for companies to meet consumer needs in the form of clothing and get potential buyers to expand market share and maintain the product life cycle.

c) The increase in the income of the population per capita has pushed the purchasing power of the Indonesian people to increase. This increase in purchasing power allows consumers to buy even more necessities including clothing needs.

d) The supply of labor that is increasingly competitive with the large number of workers who do not have jobs provides opportunities for companies to improve the quality of human resources who have skills and are highly educated so that they can achieve high work productivity.

e) The empowerment of small and medium enterprises by the government brings opportunities for companies to be more advanced through guarantee funds, consulting services, partnerships, and licensing. So that it can support the company's activities effectively and efficiently.

2. Threat

Threats are conditions that tend to harm the company with competition, and anticipatory efforts must be made immediately. The following are some of the conditions that are considered a threat to the Company:

a) The high level of competition faced by companies, especially companies engaged in the garment sector, both locally and abroad through imports. With the variety of materials and models offered by companies in this industry, it is a threat that can lead to switching consumers to competing products.

b) Import duty tariffs on imported goods in the form of garments, which are only $0 \%-15 \%$, can be a threat to companies. With the entry of products from China and other countries that have relatively cheaper prices, it is a threat that can threaten the domestic market share for local products.

c) The illegal entry of garments threatens the survival of the company as a whole in the garment industry, both used and new garments. Making companies unable to compete through low prices in the struggle for market share.

d) Regional minimum wage regulations and severance pay for employees can still be said to be burdensome for small and medium-sized businesses, wherein in this industry the entry and exit of labor often occurs. This can be a threat to the company's financial condition. 


\section{Strengths and Weaknesses}

The company's strengths and weaknesses are the results of an analysis of the company's internal environment. In a general order, the strengths and weaknesses of the companies acquired through the analysis of the internal environment are presented as follows.

1. Strength

Strength can be said as an internal advantage that a company possesses to develop its existence. The following are some of the strengths of the Company:

a) Competitive product prices will provide strength for companies to be able to compete in terms of offering prices to consumers, especially through prices that are relatively the same as closest competitors.

b) A high level of quality control, starting from the selection of raw materials, initial production to finished goods, gives the company strength to maintain good product quality and reduce errors in the production process.

c) The network of raw materials originating from within the country, as the company's strength because the materials are easily available and are not affected by fluctuating foreign exchange rates.

d) Agents that are many and scattered in big cities are a force to gather potential consumers in the existing target segment.

e) The company's current financial condition is in good condition, where so far the company has been able to generate profits and fulfill its obligations properly. This supports the company as a force to survive and grow.

2. Weakness

Weaknesses are the company's internal factors that tend to hinder the company's activities in achieving its goals. Several factors can be identified as the Company's weaknesses, including:

a) Promotional activities that are not optimal make the products produced less well known by the public. Information obtained by potential consumers as a reference for buyers who are not aware of the existence of such information, which will also determine the product life cycle becomes obsolete quickly. This could hinder the company's efforts in expanding the market.

b) The low level of human resource education will affect the performance and productivity of employees on the skills and expertise they have. So, it will affect the operating expenses and is a weakness for the company.

c) Low employee loyalty to the company is a company weakness, which makes activities within the company ineffective and inefficient. Thus, hindering the company to be able to quickly develop.

d) The variety of products produced is very limited, which only produces jeans. With a variety of garment products that can be chosen with jeans as raw material, it allows the company to increase market share in the garment industry.

e) Outdated tools and machines can make operational activities and the quality of goods decline. Thus, this weakness can be fatal for the continuity of production and sales to the consumers.

\section{IFAS Matrix Analysis}

After identifying the various strengths and weaknesses of the Company, the next step is to develop a profile of strengths and weaknesses in the internal environment using the IFAS matrix analysis tool.

Table 1. Company IFAS

\begin{tabular}{|l|c|c|c|}
\hline \multicolumn{1}{|c|}{ Internal strategic factors } & Weight & Rating & X Rating \\
\hline Strength : & & & \\
1) Competitive product prices. & 0,10 & 3 & 0,30 \\
2) High level of quality control. & 0,05 & 4 & 0,20 \\
3) Local raw material network. & 0,05 & 3 & 0,15 \\
4) Agents are many and scattered. & 0,05 & 3 & 0,15 \\
5) Good financial condition. & 0,10 & 3 & 0,30 \\
\hline Weaknesses : & & & \\
1) Inadequate promotional activities. & 0,15 & 1 & 0,15 \\
2) The level of human resource education is still low. & 0,10 & 2 & 0,20 \\
3) Low employee loyalty. & 0,10 & 2 & 0,30 \\
\hline
\end{tabular}

http://ijstm.inarah.co.id 


\begin{tabular}{|l|c|c|c|}
\hline 4$)$ Limited range of products. & 0,15 & 2 & 0,20 \\
5) Outdated tools and machines. & 0,15 & 2 & 0,30 \\
\hline Total & 1,00 & & 2,25 \\
\hline
\end{tabular}

Source: processed data

Information:

Weight:0.00 $-0.05=$ Small effect

$$
\begin{aligned}
& 0.06-0.10=\text { Medium influence } \\
& 0.11-0.15=\text { Big influence } \\
& 0.16-0.20=\text { Very big influence }
\end{aligned}
$$

Rating on IFAS matrix:

$1=$ is a major weakness

$2=$ is a small weakness

$3=$ is a small power

$4=$ is the main strength

The results of the IFAS analysis on the company presented in the table show the company's total score of 2.25. This number is below the average of 2.5 that the company's internal conditions are currently in a slightly weakened state.

\section{EFAS Matrix Analysis}

Several factors can be identified as opportunities and threats faced by the Company in achieving its objectives, the next step is to organize these factors into a profile of opportunities and threats using the EFAS matrix analysis tool.

Table 2. EFAS Companies

\begin{tabular}{|l|c|c|c|}
\hline \multicolumn{1}{|c|}{ External strategic factors } & Weight & Rating & X Rating \\
\hline Opportunity : & & & \\
1) Economic conditions are starting to improve. & 0,10 & 2 & 0,20 \\
2) The population is increasing. & 0,10 & 2 & 0,20 \\
3) Increase in the income of the population per capita. & 0,10 & 2 & 0,30 \\
4) Increasingly competitive labor supply. & 0,05 & 3 & 0,15 \\
5) Empowerment of SMEs by the government. & & 4 & 0,80 \\
\hline Threats (Threats) : & 0,15 & 4 & \\
1) High level of competition. & 0,10 & 2 & 0,60 \\
2) Import duty tariffs on imported goods are 0\% -15\%. & 0,05 & 1 & 0,20 \\
3) Illegal entry of garments. & 0,15 & 3 & 0,05 \\
4) UMR regulations and burdensome severance pay. & 1,00 & & 0,45 \\
\hline Total & &
\end{tabular}

\section{Information:}

Weight:0.00 - $0.05=$ Small effect

$0.06-0.10=$ Medium influence

$0.11-0.15=$ Big influence

$0.16-0.20=$ Very big influence

Rating on EFAS matrix:

$1=$ has very few opportunities or very large threats

$2=$ has a little opportunity or big threat

$3=$ has a big opportunity or a small threat

$4=$ has a very large opportunity or a very small threat

Based on the EFAS matrix analysis, the total weighted value is 2.95 or is above the value of 2.5 which is the average value which means that the Company can respond well to existing opportunities and avoid threats in its industrial market.

\section{SWOT analysis}

After compiling internal strengths and weaknesses as well as external opportunities and threats through EFAS and IFAS metrics, the next step is to conduct a SWOT analysis. There are two forms of SWOT analysis, namely SWOT diagram analysis, and SWOT matrix analysis.SWOT diagram analysis aims to identify one of the four patterns or cells contained in this diagram suggest strategies that can support the 
company in these conditions. In the SWOT diagram analysis, the opportunity minus scores the threat scores from the EFAS matrix and the strength scores minus the weakness score in the IFAS matrix. The difference value obtained is entered into the diagram to determine the company's conditions and alternative strategies. Based on the results of the analysis of the company's external factors on the EFAS matrix, the result is 0.35 (total opportunity scores are 1.65 minus the total threat scores are 1.30) for the opportunity factor, while the company's internal factor in IFAS is 0.05 (total strength). of 1.10 minus the total score for the weakness of 1.15 for the strength factor, then the SWOT diagram.

Fig 1. Company SWOT Diagram

Lots of environmental opportunities

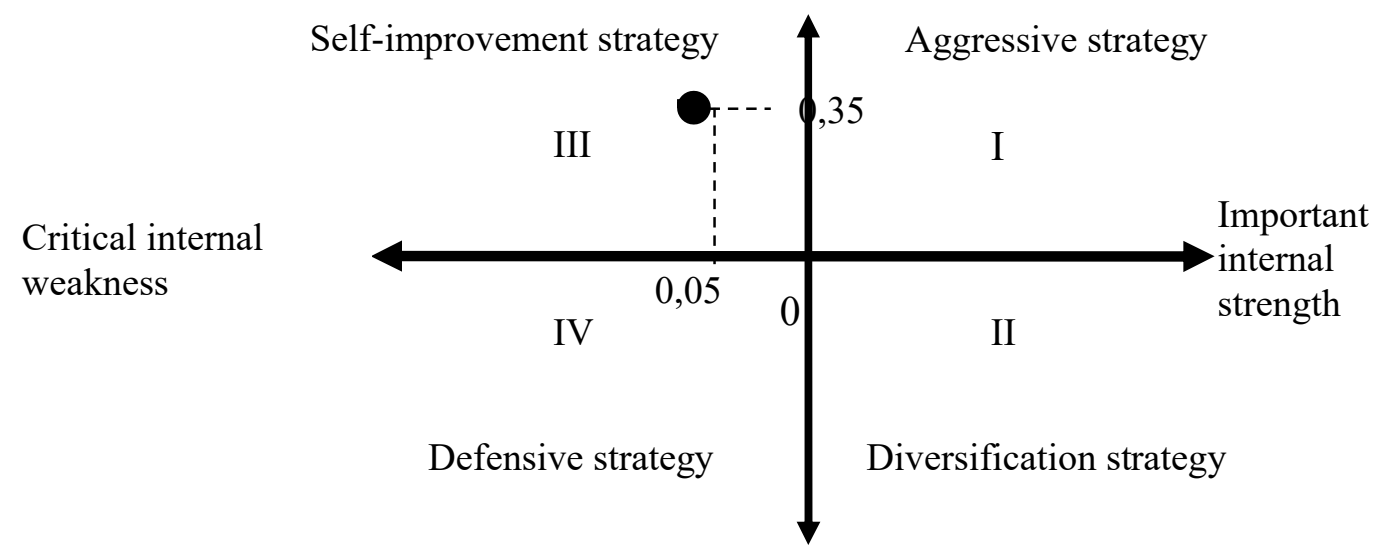

Huge environmental threat

\section{Source: processed data}

The results of the SWOT diagram show that the Company's position is in cell III, where the company faces impressive market opportunities in its external environment but is constrained by several internal weaknesses. The strategic focus for companies like this is to eliminate internal weaknesses to be more effective in taking advantage of opportunities. The situation in cell III which is included in the selfimprovement strategy, where the company is in an industry with fast market growth, intensive strategy is usually the main option that must be considered to take advantage of the current favorable situation facing the company.In addition to using a SWOT diagram, further analysis can be done using a SWOT matrix. The SWOT matrix is analyzed by adjusting the external opportunities and threats with the company's internal strengths and weaknesses, to develop alternative strategies for companies that support the strategy to improve themselves according to the company's position on the SWOT diagram.

Table 3. Company SWOT Matrix Analysis

\begin{tabular}{|c|c|c|}
\hline $\begin{array}{l}\text { SWOT Matrix } \\
\text { Company }\end{array}$ & $\begin{array}{l}\text { Strength } \\
\text { 1. Competitive product prices. } \\
\text { 2. High level of quality control. } \\
\text { 3. Local raw material network. } \\
\text { 4. Agents are many and scattered. } \\
\text { 5. Good financial condition. }\end{array}$ & $\begin{array}{l}\text { Weaknesses } \\
\text { 1. Promotional activities are not } \\
\text { optimal. } \\
\text { 2. The level of human resource } \\
\text { education is still low. } \\
\text { 3. Low employee loyalty. } \\
\text { 4. Limited range of products. } \\
\text { 5. Outdated tools and machines. }\end{array}$ \\
\hline Opportunity & SO Strategy & WO Strategy \\
\hline $\begin{array}{l}\text { 1. Economic conditions are starting } \\
\text { to improve. } \\
\text { 2. The population is increasing. }\end{array}$ & $\begin{array}{l}\text { 1. Maintain competitive product } \\
\text { prices. Maximize network agent } \\
\text { performance. }\end{array}$ & $\begin{array}{l}\text { 1. Increase promotional activities. } \\
\text { 2. Improving the quality of human } \\
\text { resources. }\end{array}$ \\
\hline $\begin{array}{l}\text { 3. Increase in the income of the } \\
\text { population per capita. } \\
\text { 4. Increasingly competitive labor } \\
\text { supply. }\end{array}$ & $\begin{array}{l}\text { 2. Conduct partnership programs } \\
\text { with large companies, dealers, } \\
\text { and suppliers. } \\
\text { 3. Conduct market penetration to }\end{array}$ & $\begin{array}{l}\text { 3. Improve or replace the technology } \\
\text { of production tools and machines. } \\
\text { 4. Develop a variety of product } \\
\text { models offered. }\end{array}$ \\
\hline
\end{tabular}




\begin{tabular}{|c|c|c|}
\hline $\begin{array}{l}\text { 5. Empowerment of SMEs by the } \\
\text { Government. }\end{array}$ & expand market share. & \\
\hline $\begin{array}{l}\text { Threat (Threat) } \\
\text { 1. The inflation rate is still quite } \\
\text { high. } \\
\text { 2. High level of competition. } \\
\text { 3. Tariff for imported goods is } 0 \% \text { - } \\
\quad 15 \% \text {. } \\
\text { 4. Illegal entry of garments. } \\
\text { 5. UMR regulations and severance } \\
\text { pay are still burdensome. }\end{array}$ & $\begin{array}{l}\text { ST } \text { strategy } \\
\text { 1. Collaborating with suppliers. } \\
\text { 2. Maintain product quality. } \\
\text { 3. Maintain product prices to } \\
\text { remain competitive in the } \\
\text { market. }\end{array}$ & $\begin{array}{l}\text { WT Strategy } \\
\text { 1. Give bonuses or awards to } \\
\text { employees who excel. } \\
\text { 2. Maximize promotional } \\
\text { activities. }\end{array}$ \\
\hline
\end{tabular}

Source: Data processed

The SWOT matrix analysis above matching the company's strengths, weaknesses, opportunities, and threats produces several strategies, namely SO, ST, WO, and WT strategies. The guidelines for selecting alternative strategies for these strategies are:

1. The SO strategy is chosen if the company has strengths in taking advantage of the various opportunities that exist.

2. ST strategy is chosen if the company has strengths in dealing with various existing threats.

3. The WO strategy is chosen if the company tries to overcome its weaknesses by taking advantage of the various opportunities that exist.

4. The WT strategy is chosen if the company tries to overcome its weaknesses while avoiding the threats it faces.

Various alternative strategies need to be prioritized based on a combination of SWOT matrix analysis and SWOT diagrams. The self-improvement strategy in the SWOT diagram focuses more on intensive efforts to improve the company's competitive position, which when compared to the SWOT matrix in the WO strategy, it is found that the company has many opportunities and weaknesses to anticipate, namely with the main strategy in the form of market penetration, market development, and product development. Market penetration is prioritized because with this strategy the company is expected to be able to maximize the role of its network of marketing agents by taking advantage of existing opportunities by increasing its market share. Market development is prioritized because through this strategy the company is also able to increase its market share through the introduction of new regional products. Meanwhile, product development is used as the main alternative strategy in the hope that the company will develop products through increasing or modifying the existing product range.

\section{CONCLUSION}

Based on the results of the analysis that has been carried out on the internal and external aspects of the company, the conclusions that can be drawn from this research are:

1. The company needs an appropriate strategy to survive and thrive in its industry. In implementing the company's strategy, to analyze various internal conditions and external conditions of the company that can affect the course of company activities and the achievement of company goals.

2. The results of the EFAS matrix analysis with a total score of 2.95 show that the company is in an aboveaverage position in responding to existing opportunities and avoiding threats in its industrial market. While the results of the IFE analysis with a total score of 2.25 show that the company is below average or slightly weak to take advantage of its internal strengths and minimize its weaknesses.

3. Based on the results of the SWOT and IE analysis, the alternative strategies analyzed show that the company has an alternative hold and maintenance strategy (maintain and maintain). This strategy focuses on efforts to maintain the capabilities of the company and use them to seize the opportunities that exist. Market penetration and product development are strategies that are usually applied by companies in this position. Market penetration aims to increase market share with maximum marketing efforts, while product development aims to increase sales by increasing and modifying existing product ranges. 


\section{ACKNOWLEDGMENTS}

The author would like to thank everyone and society for their support and encouragement throughout the process until the completion of this research. It is hoped that it can be used as reading material to add insight and views of readers about marketing strategies, as well as a source of reference and information for the same research size as well as a comparative study in the context of studying science.

\section{REFERENCE}

[1] Amirullah. 2002. Consumer behavior. Yogyakarta : Graha Ilmu

[2] Arikunto, Suharsimi. 2002. Research Procedure (A practical approach). Jakarta: PT. Rineka Cipta

[3] Boyd, Walker, and Larreche. 2000. Marketing Management (A Strategic Approach With a Global Orientation). Jakarta: Erlangga..

[4] Chandra Gregory. Marketing Strategy and Program. 2005. Yogyakarta: Andi

[5] Jerome and William. 1996. Marketing Basics. Jakarta: Erlangga

[6] Kotler, Philip. 1997. Marketing Management. Jakarta: Prenhallindo

[7] 2003. Marketing insights from A to Z. Jakarta: Erlangga

[8] Kotler, Philip, and Armstrong. 2001. Marketing Principles (Volume 1). Jakarta: Erlangga..

[9] Moleong. 2000. Qualitative Research Methodology. Bandung: PT. Rosdakarya

[10] Mulyana, Deddy. 2003. Qualitative Research Methodology (New paradigm of communication science and other social sciences). Bandung: PT. Rosdakarya Teens

[11] Pearce, John, A. \& RB Robinson. 1996. Strategic Management (Translation by Agus Maulana. 1997). Jakarta: Character Building Bin

[12] Swastha, Basu. 1984. Marketing Principles. Yogyakarta: Liberty 